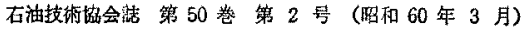

JOURNAL OF THE JAPANESE ASSOCIATION FOR PETROLEUM TECHNOLOGY

VOL. 50, NO. 2 (March, 1985)

\title{
ネットワークモデルによる浸透率の推算値と実測値の比較
}

\author{
千田 佶*.田 中正 三* \\ （昭和59年 6 月15日受付，11月22日受理）

\section{Comparison between Estimated Values of Permeability based on a Network Model and Experimental Ones}

By

Tadashi CHIDA and Shozo TANAKA

\begin{abstract}
A pore size distribution of a porous medium is estimated, and using the distribution, permeability is also calculated on the basis of a two-dimensional network model.

The calculated values of permeability are compared with experimental ones. The calculation agrees well with the experimental results, when the size of the network is large enough. The agreement is better than that between the experimental values and the estimation on the basis of Carman's equation.
\end{abstract}

\section{1. 緒言}

先に著者ら（千田・田中(1983)）は二次元ネットワー クモデルを用いて孔幥径分布と浸透率の関係について諭 し，分布の広がりに応じて浸透率が変化することを示し た。そして，毛細管束モデルから求められる浸透率と拣 測値の美異修正するための補正保数（Purcell の係数） を理論的に求めることをる示した。

また著者ら（千田・酒井・田中(1984））恃多孔質体中 への毛細管力に上る液体の漫透举動を二次元ネットワー クモデルにより解析した。そして，浸透時䦭が短く，浸 透高さが平衡高さに比へてて低い場合には液体は完全に孔 隚を満たしているが，浸透高さが高くなってくると液体 の浸透は不完全となり液体の浸透が不可能な孔陵の存在 することを示した。さらにこの結果から，多孔質体の 孔隙径分布を求めることも示した。しかし，この孔隙徍 分布を求めるにあたってはモデルに含ま执るいくつかの パラメータを同時に決定しなければならないためそれら のパラメータの值の組み合わせに多少の任意性が伴ら恐 れがあった。

本論女はこの上うにして得られた孔鄚径分布から前報 （千田・田中(1983)）の方法で浸透率の理諭值を求め， 実測の漫透率と比較することにより上述の上らにして求 められた孔償径分布が妥当ないのであるかどうかを检討 するすのであ。

\section{2. 浸透率の推算}

いま，前報（千田・酒井・田中(1984)）と同様にして

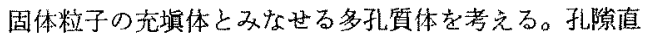
佳をdとし，その代表值として次式

$$
d_{a \downarrow}=4 \varepsilon / S(1-\varepsilon)
$$

で定義される水力直径 $d_{a b}[\mathrm{~m}]$ をとり，無次元直佳 $D$ を次のよう火定義する。

$$
D=d / d_{\text {ev }}
$$

ただし(1)式中の $\varepsilon$ は多孔質体の孔償率， $S\left[\mathrm{~m}^{2}\right]$ は充嫃粒 子の比表面積であり次式で表される。

$$
S=6 / D_{p}
$$

$こ こ に D_{p}$ は充镇粒子の平均径である。

多孔筫体を図1に示すように一定長さで直径に分布の ある $M_{s}$ 個のせグメントから構成される二次元ネットワ 一クで表現できるものとする。このとき，各せグメント の直径は前報と同様にして定める。すなわち，四2のよ
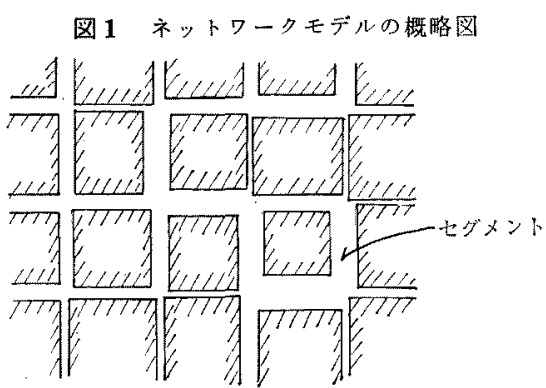


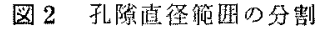

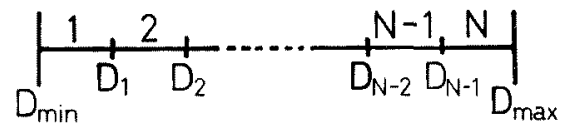

5に最小直径 $D_{\min }$, 最大直径 $D_{\max }$ を必要な大きさに とり，区間 $\left[D_{\mathrm{min}}, D_{\mathrm{max}}\right] を D_{1}, D_{2}, \cdots, D_{N-1}$ により $N$ 個の小区間飞分割子る。各七がントの直径はかなら ずいずれかの小区間に属しているはずで方り，その所薥 区間を筷似乱数老用いて泛定ずることができる。そのと き各小区閶に分配される七グメントの平均個数は $M_{s} / N$ 個である。このとき分割点 $D_{1}, D_{2}, \cdots, D_{N-1}$ の決䇥法が

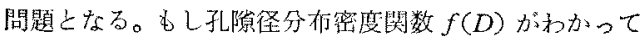
执れ优, 次式

$$
\int_{D_{n-1}}^{D_{n}} f(D) d D=\frac{1}{N}
$$

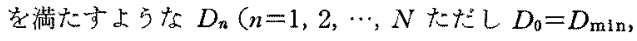

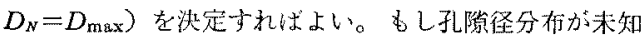
であれば(3)式による $D_{n}$ の沠定はできない。この場合に は前報の上5に放らかし $D_{n}(n=1,2, \cdots, N-1)$ の值

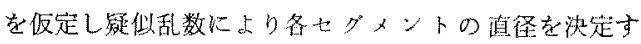
る。この上らにして決定された二次元ネットワーク教用 いて，例えば海細管力による多孔躓体中心の液体の浸透 挙動を解析し，実験絈果と比較することができる。る し，解析結果と东测結果が一致しなりれい゙，改めて $D_{n}$ $(n=1,2, \cdots, N-1)$ の值を仮定しな祘世优よい。前報 に招いて上述の試鿁法を用いて $D_{n}(n=1,2, \cdots, N-1)$ の值を求めた一例は以下の上らである。

すなわち， $D_{\min }=0.01 ， D_{\max }=2.3$ ととるとき $D_{1}$, $D_{2}, \cdots, D_{N-1}$ の值は, $0.5,0.9,0.94,0.96,0.975$, $0.985,0.995,1.0,1.005,1.015,1.025,1.04,1.06$, $1.085,1.11,1.135,1.16,1.19$ そして1.25である。こ 扎らの值は直径 $8 \mathrm{~mm}$ のガラス管に光翼した直径約 0.1 $\mathrm{mm}$ のガラス粒子層に打ける液体漫透量の奏測結果と末 ットワークモデルによる解析絬果との此校から求められ たものである。 $D_{n}(n=1,2, \cdots, N-1)$ の值がわかれば

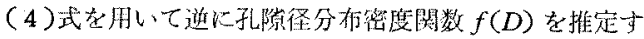
ることができる。それを示したのが図３である。直径䊆

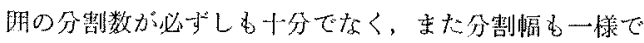

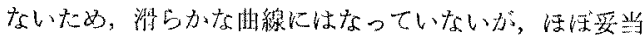
な孔陪隹分椎を示していると思う。

ネットワークモデルによる解析に扎いては疑似乱数を 用いて沶り，さらK $D_{n}(n=1,2, \cdots, N-1)$ の值定試 渱法により決定しているので， $D_{n}$ の值は確定的なるの ではなくある程度の任意性をるっている。したがって例

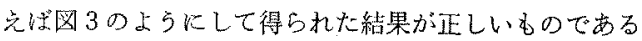
かどうかを別の観点から検討する必要がある。ここでは
图3ネットワークモデルを用いて求めた孔隚径分布

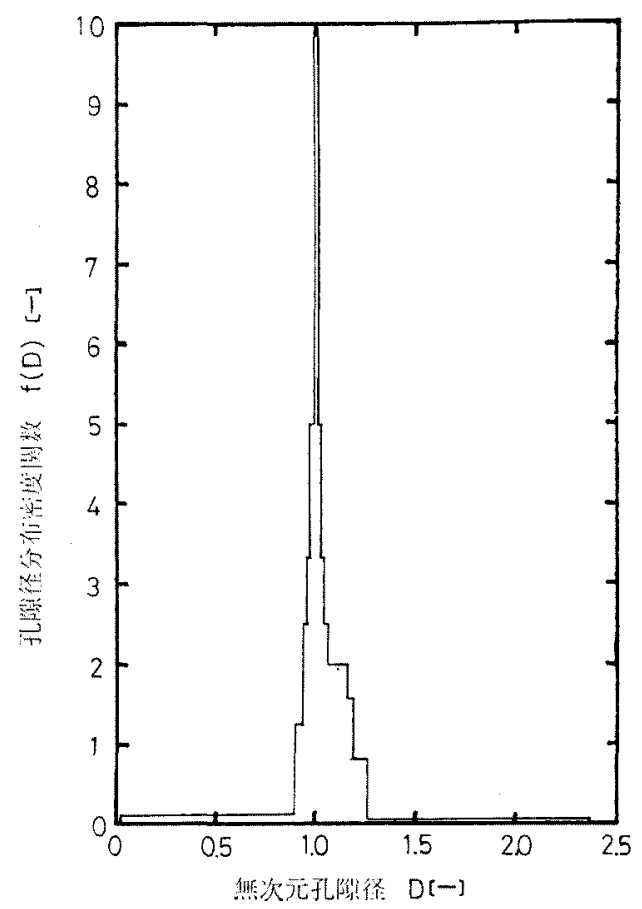

図 4 䁈次元浸透率Kとネットワークの大きさを示すパ ラメータ $N_{s o}$ の関倸

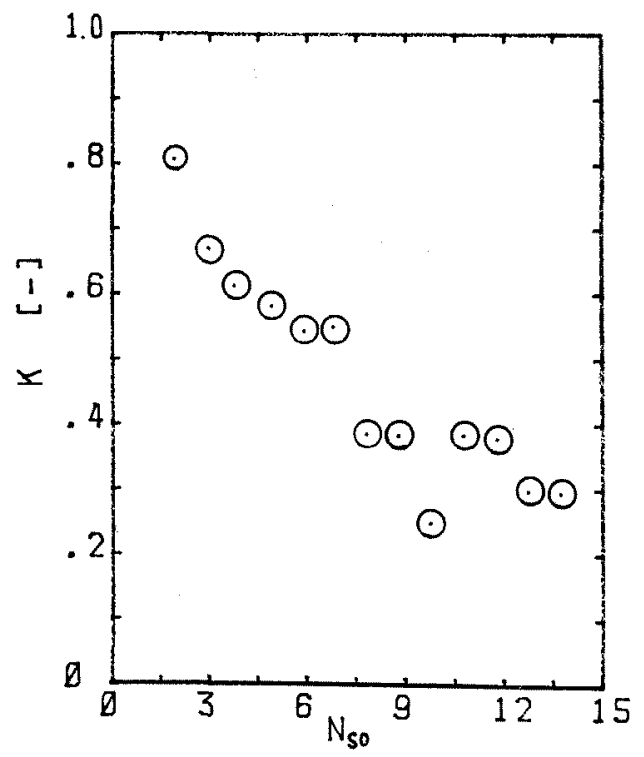

前報(千日十・日中(1983))で述べた方法に上り孔箵径分布

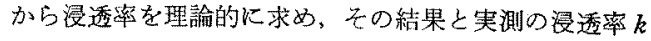
との比較を行らことにより，上述の力法により求めた孔 
戃径分布の妥当性を検尉する。前報（千田・田中(1983)） に従い前述の $D_{n}(n=1,2, \cdots, N-1)$ の值をとのまま

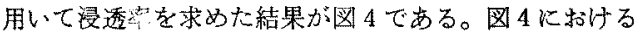
粉軸のKは次式

$$
K=32 k / \varepsilon d_{c v}{ }^{2}
$$

で定䉝され，無次元浸透率ともいうべきものである。こ こにと[一]は孔隍率， $d_{00}$ はネットワークモデルに和け る細孔セグメントの平均径である。李な横軸の $N_{s a}$ は二 次元ネットワークモデルの一辺を權成するセグィントの 数であり，このときホットワークの全セグィント数 $M_{s}$ は

$$
M_{s}=2 N_{s u}\left(N_{s u}+1\right)
$$

である。

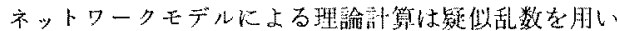
ているためKの䛧にはばらつきがるれるが，全体的な

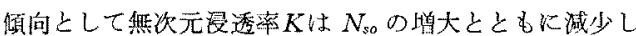
$N_{\text {so }}>10$ で汪活 $K \approx 0.3$ 程度の值になることがわかる。

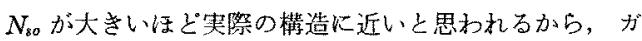
ラス充㙋層への浸透量上り求め大孔隚径分布を用いて計 算した無次元漫透率 $K$ は約0.3であることが予想される。

前報（千田・田中(1983)）でも述べたように無次元浸 透率Kは Purcell の倸数と同じのと教立られる。本研 究で対象としたガラス无填層の Purcell の係数は注活0.3 といらことになる。

\section{3. 実験および結果}

汹 5 に示す上5な簡単な装置を用いてがラス充埧層の

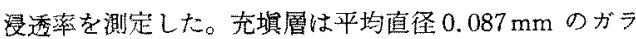

図 5 寒験装置

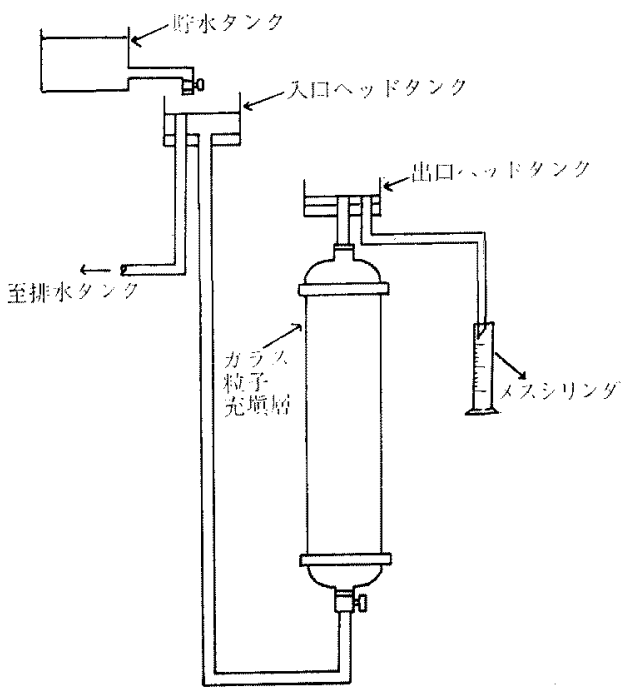

ス粒子を值径 $73 \mathrm{~mm}$ ，高さ $410 \mathrm{~mm}$ のアクリル製丹管に 充塤したるので孔隚率 $\varepsilon$ は約0.36である.

入り口ッッドダンクの高さを調節することにより入出

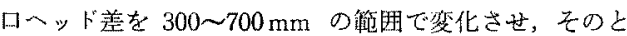
きの液流量を測定した。王力美 $\Delta P[\mathrm{~Pa}]$ 和上び液流量 $Q\left[\mathrm{~m}^{3} / \mathrm{s}\right]$ 加ら次式により浸透摔 $k\left[\mathrm{~m}^{2}\right]$ を求めることが でさる。

$$
k=\frac{Q}{A} \mu \frac{L}{\Delta P}
$$

ただし，Aは断面䄼 $\left[\mathrm{m}^{2}\right] ， \mu$ は粘度 $[\mathrm{Pa} \cdot \mathrm{s}] ， L$ は允埧 層琴さ $[\mathrm{m}]$ である。

州いた液体は水抽よ゙ヶロシンの 2 程でる。ケロシ

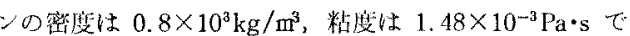
ある。

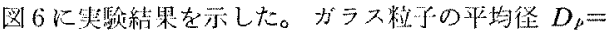

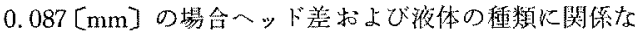
く浸透率の值は汪ほ $k=4.3 \times 10^{-12}\left[\mathrm{~m}^{2}\right]$ となっている。 この困には充填がラス粒子值径 $D_{P}=0.1$ 捻上び 0.18 の 場合む示してある。

图 6 浸透率的睡定結果

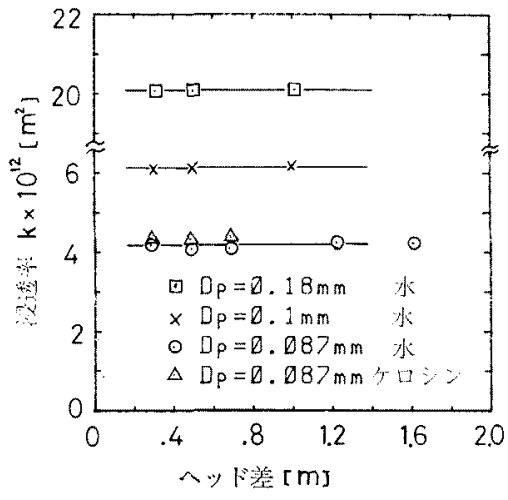

\section{4. 考察}

測定された漫透率 $k$ の值和上び実駼多件上り(5)式と同 様に契測值に基づいた照次元浸透率 $K_{e x}$ を得ることがて

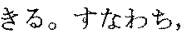

$$
K_{e, s}=32 k / \varepsilon d_{a v}^{2}
$$

である。(8)式より求めた

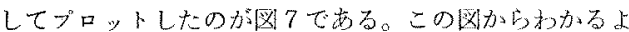

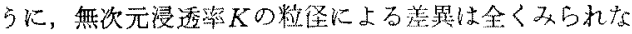
い。もちろ九液物性による差異はない。また，実測值に 基ついた舆次元浸唀率 $K_{\text {ex }}$ の值は0.32，0.34であり，兄 の平为は0.33己なっている。

二次元ホットワークモデルからガラス籿子㬝への渡体

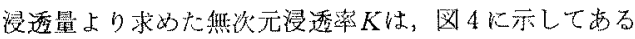


图 7 寒測值加ら求的た無次元漫透率

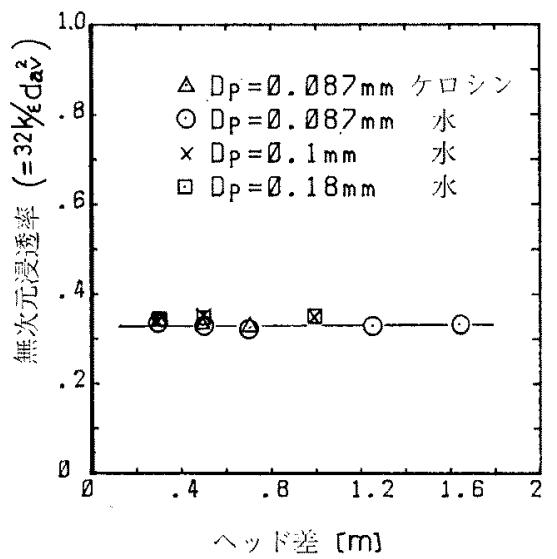

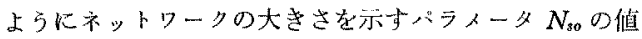
に上って多化する。 $N_{s o}=10 \sim 13$ 程度のところではぼ $K=0.33$ となって牤り，ほぼ夹測值に基づいた無次元漫 透率 $K_{e x}$ の值に近い。 $K$ の值は $N_{s o}$ の值が十分大きい ところで $K=0.3$ とっているが $K_{e x}$ はこの値とも近似 的に一致して和り，二次元ネットワークモデルKよる解 析が妥当なものであることがわかる。

CARMAN（1937）によれば，浸透率 $k$ は次式で表現さ れる。

$$
k=\frac{\varepsilon^{3}}{C S_{a}^{2}}
$$

ここにCはKOZENY の定数であり, 球形稙子の充境層 の場合通常 $C=5$ である。また， $S_{a}$ は次式で定義される 比表面榡である。

$$
S_{a}=\frac{6(1-\varepsilon)}{D_{p}}
$$

$S_{a}$ は(2)式で定義した $S$ と次の関俰が妿る。

$$
S_{a}=S(1-\varepsilon)
$$

W蛙，長さ $l_{p}[\mathrm{~m}]$, 直径 $d_{a v}[\mathrm{~m}]$ の电細管が $1 \mathrm{~m} \times 1 \mathrm{~m}$ の断面積当たり $N_{p}$ 本存在するよらな細孔棈造を考兄 る。毛細管一本の体積は $l_{p} \pi d_{\Delta v}{ }^{2} / 4$ であり，また毛細管 全体積が多孔質体の全孔隚率をに等しいことより次式を 得る。

$$
N_{p} l_{p} \pi d_{a v}{ }^{2} / 4=\varepsilon \times 1 \times 1 \times l_{p}
$$

したがって，

$$
N_{p}=4 \varepsilon / \pi d_{\mathrm{ap}}{ }^{2}
$$

となる。ところで，毛緗管一本当たりの表面積は $\pi d_{a v} l_{p}$ であるから，比表面積 $S_{a}$ は次のようになる。

$$
S_{a}=\frac{N_{p} \pi d_{a v} l_{p}}{1 \times 1 \times l_{p}}=N_{p} \pi d_{a v}
$$

(14)式に(13)式を代入すれば炏式を得る。

$$
S_{a}=4 \varepsilon / d_{a v}
$$

（15)式を(9)式に代入すれば次式を得る。

$$
k=\frac{\varepsilon d_{a v}{ }^{2}}{16 C}
$$

（16）式を（5）式に代入し，C=5とすれぱ CARMANKOZENYの式にしたがう場合の無次元浸透率 $K_{c}$ を得る ことができる。すなわち、

$$
K_{\mathrm{c}}=0.4
$$

となる。

本害験はガラ入粒子充填層であるから CARMAN-

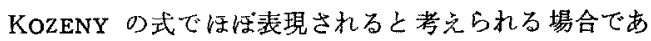
るが、CARMAN-KOZENYの式から求めた無炊元漫透率

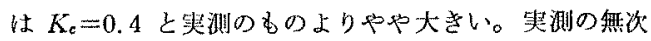
元浸透率 $K_{e x}=0.33$ と $K_{\mathrm{c}}$ が一致するためには(16)式に おける KOZENY の定数を躲略 $C=6$ としなければなら ない。

CARMAN（1937）は，ガラス粮子を充垻した場合に KOZENY 定数は车駼的に $C=5 \sim 6$ となりうることを示

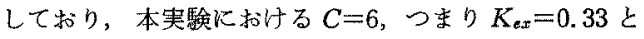
なることは妥当なものであるう。つまり, CARMANKOZENY の式では $K_{e x}=0.33$ を説明するのに KOZENY 定数 $C$ を実験的に修正する必要があることがかかる。一 方，二次元ネットワークモデルでは孔隙径分布に基づい て理論的に求めた無次元浸透率は十分实測值加計算さ れた值に近いことがわかる。

図 3 に示した孔隚径分布密度関数は分布の裙が広が。 た形をしており，単純な理諭分布式では近似できないよ らである。もし，実測の分布が理諭分布式で近似的にで る表現できるようであれば，前報で述べたよらに無炊元 浸透率Kは孔隚径分布の眐準偏差 $\sigma$ に上り变化し，同し

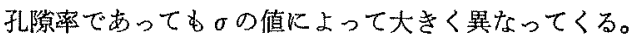
この点か;, CARMAN-KOZENY の式と二次元ネットワー クモデルの大きな差である。CARMAN-KOZENYの式を 用いて来测做を整理するとき種々の補正を必要とする が，むし二次元ホットワータモデルを用いれば孔裳径分 布から直接浸透率を汪とんど修正することなく得ること ができる。

以上のことから，多孔質厤への液体浸透量より求めた 孔渻径分布が，はとんど任意赀を伴わずに使用可能であ ることもかかる。

\section{5. 結咅}

前報の多孔質層への液体浸透量上り求めた孔㗂径分布 に基ついて二次元ネットワークモデルを用いて理論的に 浸透率を求め実测值と比較したところ，理諭値と丰测值 の一致は函めてよいことがわかった。また，CARMANKOZENY の式より求めた浸透率は㬰測值のてれよりや 
や大きい值であり，CARMAN-KOZENY の式を用いるた めには KOZENY の定数を修正する必要があることるわ かった。

以上のことより，多孔質層への液体浸透量から二炏元 ネットワークモデルを用いて求めた孔隙径分布は妥当な あのであることがわかった。

なお，本研究への有益なご助言をいただいた下飯坟潤 三教授(東北大学工学部)，本実験を進めるにあたり御助 力をいただいた上杉恭弘(現エッソスタンダード石油(梸)

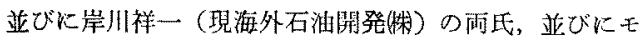
デル計算に御助力をいただいた田中桂助非（東北大学工 学部)に謝意を裁し委す。

\section{記号}
$A:$ 断面楮
$C$ : KOZENY D定数
$D$ : 無次元直径 $\left(=d / d_{a v}\right)$
$D_{p}$ : 充塓粒子の平均直径
$d:$ 孔隙㨁径
$d_{a v}$ : 平均孔隙直径
$f(D)$ : 確率密度関数
$K:$ 無次元浸透率 (=32 $\left.k / \varepsilon d_{a v}^{2}\right)$
$K_{c}$ : CARMAN $の$ 式に基づく $K$
$K_{\text {ex }}$ ：実験結果に基づく $K$

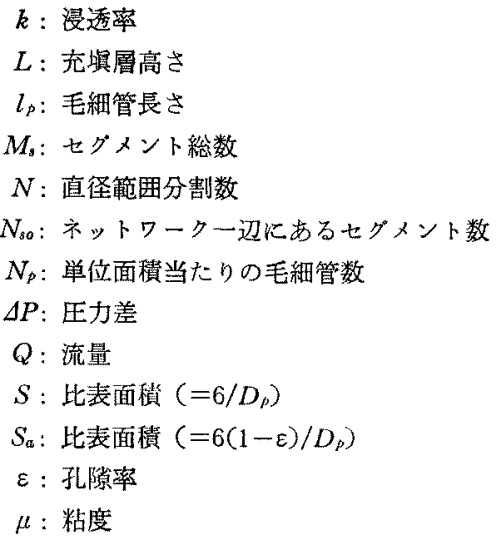

\section{引用 文 献}

千田 侸・田中正三(1983)：ネットワータモデルによる

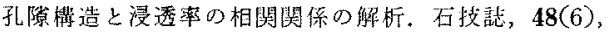
439-444.

千田佶・酒井昇・田中正三(1984)：多孔質体内の毛

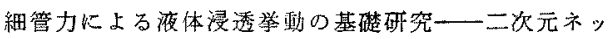
トワークモデルによる解析一. 石技誌，49(4)，207221.

CARMAN, P.C., (1937): Fluid Flow Through Granular Beds. Trans. Chem. Engrs., London, 15, 150. 